\title{
Hemocompatibility Evaluation of Two Antimicrobial Peptides, Plantaricin CS and Snakin Z H Zare-Zardini ${ }^{1,2}$, MR Sobhan ${ }^{3}$, A Rezaei ${ }^{4}$, K Arab-Badkubeh ${ }^{4}$, Z Hahsemian ${ }^{5}$
}

\begin{abstract}
Objective: Plantaricin CS and Snakin Z are two peptides that purified from innate immune systems of two different species. Because of their biological activities, the use of these peptides in a variety of medical applications is possible. For this purposes, investigation of hemocompatibility and cytotoxicity of peptides is necessary.
\end{abstract}

Methods: Human red blood cells (RBCs) were treated with different concentration of peptide in two methods: radial diffusion assay and spectrophotometric assay. For in vivo assay, the mean of hematocrit, RBCs and White Blood Cells (WBCs) was assessed after treatment of 48 rats (24 rats for each peptide) with different concentrations of peptides $(5,15,45,135$ and $400 \mu \mathrm{g} / \mathrm{ml})$ for two weeks.

Results: According to data, no significant changes were observed in the groups treated with Plantaricin CS in all concentration; but Snakin $\mathrm{Z}$ showed significant toxicity on all blood cells. This peptide decreases the RBC, WBC and Hematocrit as $4.1 \mathrm{RBC} \times 1000000 / \mu \mathrm{L}, 12 \mathrm{WBC} \times 1000 / \mu \mathrm{L}$ and $16 \%$ in concentration of $400 \mu \mathrm{g} / \mathrm{ml}$, respectively.

Conclusion: According to this study, both of peptides showed hemocompatibility in values that they have biological activities. So it's suggested that Snakin Z and Plantaricin CS may be suitable pharmaceutical agents.

Keywords: Antimicrobial peptides; Blood Cells; cytotoxicity; Hemocompatibility; Plantaricin CS; Snakin Z From: ${ }^{1}$ Young Researchers Club, Yazd Branch, Islamic Azad University, ${ }^{2}$ Hematology and Oncology Research Center, Shahid Sadoughi University of Medical Sciences and Health Services, ${ }^{3}$ Department of Orthopedia, Shahid Sadoughi University of Medical Sciences, ${ }^{4}$ Department of pathology, Shahid Sadoughi Hospital, Shahid Sadoughi University of Medical Sciences and Health Services, ${ }^{5}$ Main hospital of Shahid Sadoughi, Shahid Sadoughi University of Medical Sciences and Health Services, Yazd, Iran.

Correspondence: Dr H Zare-Zardini, Department of Biotechnology, Faculty of Advanced Sciences and Technologies, University of Isfahan, Isfahan, Iran. Fax: (0098) 353-8229104, e-mail: hadizarezardini@gmail.com 


\section{INTRODUCTION}

Antimicrobial peptides (AMPs) are important natural compounds that distribute in all of organisms from prokaryotes to primates $(1,2)$. The main actions of these peptides are disruption of the structure or function of microbial cell membranes and are synthesized in response to infection or inflammation $(3,4)$. These agents have different useful other biological activities so that there is possibility to develop and introduce them as new drugs for treatment and prevention of various diseases (5-9).

Plantaricin CS and Snakin Z are two antimicrobial peptides that identified and purified from Coriandrum sativum and Ziziphus jujuba, respectively $(10,11)$. These two AMPs are member of innate immune system. Plantaricin CS and snaking Z was purified from two plant species. These two peptides have potent antimicrobial activities against different gram positive and gram negative bacterial and fungal pathogens $(10,11)$. According to our pervious study, Snakin $\mathrm{Z}$ has also inhibitory activity against two important enzymes, acetylcholinesterase (AChE) and butyrylcholinesterase (BChE) as well as antioxidant activity (5).

We also showed that these peptides have low hemolytic activity against human red blood cells in in vitro $(10,11)$. So, all two peptides have suitable properties for development as new drug in different field of medicine especially as antimicrobial drugs. Snakin Z are suitable properties that may be beneficial in the treatment of Alzheimer's disease (AD). For introduce a compound as new drug, the most important test is hemocompatibility $(12,13)$. The compound with high hemolysis activity leads to dangerous effect on body's condition (14-16). So, the hemolytic properties of these compounds should be evaluated. Thus, the aim of this present study is evaluation of effect of these three peptides on hematocrit, Red and white blood cells as in vivo study. The hemolysis activity of these peptides was also compared in in vitro study. The results 
of this study can complete our previous studies so that we can develop these two peptides as new drugs with more confidence.

\section{MATERIALS AND METHODS}

\section{Peptide preparation}

Plantaricin CS and Snakin Z were synthesized by Fmoc solidphase using an Applied Biosystems Model 432A Synergy peptide synthesizer according to previous study. Purification was done by The RP-HPLC on a C18 semi-preparative column. The column was washed by gradient of acetonitrile with flow rate of solvent was $2 \mathrm{ml} / \mathrm{min}$.

\section{Experimental design}

In vivo Hemocompatibility assay

48 male rats (with weight $60-150 \mathrm{~g}$ ) were housed in in clean cages under standard experimental condition. 48 rats were divided 2 groups: one group containing 24 rats for Snakin $\mathrm{Z}$ and another group containing 24 rats for Plantaricin CS. Then, in each group, the 24 rats were divided into six groups (I-VI) so that one group (I) was applied as control group. In these 2 control groups, rats were treated by $1 \mathrm{ml}$ of normal saline for 21 days. Other groups were treated by $1 \mathrm{ml}$ of different concentration of two peptides for a same period (21 days). The values of peptide concentration in groups II-VI are summarized in table 1. This protocol was repeated for three weeks. On the 22st day, blood samples were collected from all groups and haematological parameters containing hematocrit, white and red blood cells value was assessed by a cell counter device (model Horiba, France). All results were collected and comprised and also statistical 
analysis was carried out by SPSS software. The hemolytic activity of two peptides in in vivo was calculated by below equation:

Hemolytic rate $(\%)=A-B / C-B^{\times 100}$

In this equation, $\mathrm{A}$ is absorbance values of nanostructures, $\mathrm{B}$ and $\mathrm{C}$ are absorbance values of negative and positive control group respectively.

In vitro Hemocompatibility assay

The effects of Snakin Z and Plantaricin CS on erythrocyte were also examined in in vitro. For this, two methods were applied: Radial Diffusion Assay (RDA) and spectrophotometric assay. Two methods was done base on our previous studies. In RDA method, the serial dilutions of peptides in table 1 were loaded at wells on blood agar plates containing diluted RBC. These plates were incubated at $37^{\circ} \mathrm{c}$ for $30 \mathrm{~min}$. the hemolytic effect appeared as a clear zone around the wells. TritonX-100 was used as a positive control. In spectrophotometric assay, $10 \mu$ the serial dilutions of peptides were added to each tube containing $190 \mu \mathrm{L}$ of diluted $\mathrm{RBC}(10 \%$ cells) and then, they were incubated for $30 \mathrm{~min}$ at $37^{\circ} \mathrm{C}$. After this time and centrifugation of tubes, supernatant solution was diluted with PBS. The absorbance at $567 \mathrm{~nm}$ was measured. Triton $\mathrm{X}-100(0.1 \%)$, which yields $100 \%$ hemolysis, was used as a positive control. The results were compared with the control.

\section{Structure prediction}

The peptides structure was predicted based on the structure of most similar of peptides to these two peptides and helical wheels were drawn. The chemical properties of Snakin $\mathrm{Z}$ and Plantaricin CS were also calculated and summarized in Table 2. The hydrophobic moment $(\mu)$ of two peptides were also calculated using the Eisenberg's scale for hydrophobicity and moment method (17). 


\section{RESULTS}

\section{In vitro hemolytic activity}

The hemolytic activity of Snakin Z and Plantaricin CS toward human RBCs was tested. The results are shown in Figure 1. Figure 1 showed the hemolytic activity using RDA method. According to this figure, these two peptides showed no significant hemolytic activity in concentration that they have biological activities. At the highest concentrations of the peptides (400 $\mu \mathrm{g} / \mathrm{mL}$ ), Snakin $\mathrm{Z}$ and Plantaricin CS showed $25 \%$ and $8 \%$ hemolytic activities on RBC in comparison with Triton X-100, respectively. The absorbance method showed the similar results (figure 1). This indicated that there is a weak interaction between the Snakin $\mathrm{Z}$ and Plantaricin CS and phospholipids of RBCs especially for Plantaricin CS. The results also showed that the RBCs showed better tolerance in the presence of Plantaricin CS peptide than Snakin-Z.

\section{Hematological results}

The effects of two peptides on hematological parameters were investigated in in vivo. The values of hematocrit and number of RBC didn't change after incubation with different concentrations (Figure 2 and 3). So, a statistically considerable drop in RBCs was happened in the presence of Snakin $\mathrm{Z}$ at concentrations of $135 \mu \mathrm{g} / \mathrm{ml}$ and $400 \mu \mathrm{g} / \mathrm{ml}$ (Figure 2). As shown in these figures, there is a low change in values of hematocrit and number of RBCs in Plantaricin CS. In Snakin-Z group, there was linear relationship between increase of peptide concentrations and reduce Hematocrit and the number of RBCs. The effects of various concentrations of Snakin-Z and Plantaricin CS on WBC were shown in Figure 3. Both of two peptides increase the average number of WBCs as non-linear graph. In between, the effect of Snakin-Z was more than Plantaricin CS. The data showed that the average number of WBCs increased in concentration of 5, 15 and 45 and $135 \mu \mathrm{g} / \mathrm{ml}$ of two peptides and the higher concentrations, it decreased. These 
changes were more obvious in Snakin-Z than Plantaricin CS. Plantaricin CS increase the WBC until specific concentrations, but its effects on decrease of WBC was not significant.

\section{DISCUSSION}

Antimicrobial peptides are the one of agents that exists in innate immune system in all of organisms $(18,19)$. This peptides support them against different microbial pathogens such as bacteria, fungi, viruses and etc. there are other suitable effects for some of these peptide that was proven by many researchers (20). AMPs also exist in plant that was produces AMPs in all their organs either constitutively or in response to microbial infection (21).

Snakin $\mathrm{Z}$ is one of these peptides that purified from Ziziphus Jujuba. This peptide has strong antimicrobial activity against bacterial and fungal pathogens (11). This peptide also showed antioxidant activity as well as inhibitory effect on cholinesterase. In our previous study this peptide was introduced ac antimicrobial and antioxidant agents. This peptide was introduces as agents for treatment of AD (5). Plantaricin CS is the other AMP that identified from Coriandrum sativum. This peptide showed inhibitory activities against bacteria and fungi. So, these peptides have potent biological activities. For use of these peptides as medicinal agents for prevention of infectious diseases, antioxidant agents and treatment of $\mathrm{AD}$, the evaluation of their

effects on hematological parameters is necessary. Results of this study showed that Snakin-Z and Plantaricin CS has suitable activity on hematological parameters.

We also showed that Plantaricin CS has very low toxicity in highest concentration. Snakin-Z has more toxic than Plantaricin CS. The used range of concentration was designed according to MIC values of these peptides. Based on our previous studies, the MIC values of Snakin $\mathrm{Z}$ is the range of $7.65-28.8 \mu \mathrm{g} / \mathrm{ml}$ and this value is the range of $35.2-62.1 \mu \mathrm{g} / \mathrm{ml}$ for 
Plantaricin CS. So, we prepared 3 concentrations for each peptide in two ranges $(5,10,45$ $\mu \mathrm{g} / \mathrm{ml}$ ). Two high concentrations were prepared and used out of MIC ranges (135 and 400 $\mu \mathrm{g} / \mathrm{ml})$. These concentrations were used for confidence of suitability of two peptides. The compartion between two peptides indicated that the mean decrease of red blood cells and Hematocrit in Snakin-Z groups was very higher than Plantaricin CS groups so that this decrease was increased linearly in groups treated by Snakin-Z, but there were no any significant changes in groups treated by Plantaricin CS. However, the changes of these hematological factors were not significant in Snakin-Z groups at MIC values of Snakin-Z as well as its concentration that has antioxidant and anti-cholinesterase activities. The observed difference of hemolytic activity between these peptides is related to their different chemical properties especially hydrophobicity.

According to table 2, the hydrophobicity of Snakin Z is more than Plantaricin CS. The hydropathy value of Snakin Z is more positive than Plantaricin CS. Many articles were proven that there is a relationship between hydrophobicity and hemolytic activity. Hydrophobicity of peptides effect on their hemolytic activities (22-25). According to these articles, this relationship is because the phospholipids composing the membrane of red blood cells. The membrane of normal mammalian cells especially red blood cells is composed predominantly of zwitterionic phosphatydil choline and sphingomyelin phospholipids. Thus, the peptide with higher hydrophobicity can interact with membrane and show higher hemolytic activity than peptide with lower hydrophobicity $(23,25)$.

According to helical wheels of Snakin-Z and Plantaricin CS (Figure 4), their side chains are oriented in an amphiphilic arrangement, with all charged residues separated to one face of the helix. In table 2, hydrophobic moment $(\mu)$ value for Snakin-Z is also more than Plantaricin CS. According to Dathe et al article, increase of $\mu$ enhances haemolytic activity (23). Thus, it's possible that Snakin Z has higher hemolytic activity than Plantaricin CS. The data of this study proved this 
possibility. The effects of two peptides on WBC showed that both peptides stimulate immune system as increase of WBC. But at very high concentration, Snakin-Z peptide decreases the WBC by destruction of membrane. Similar to RBC, higher hydrophobicity can interact with WBC membrane and show higher activity. So, Snakin-Z has high toxicity on WBC. According to this study, Snakin-Z and Plantaricin CS has low adverse effects on hematological parameters. In between, Plantaricin CS has more suitable conditions. The effects of these two peptides on RBC, WBC and hematocrit have low at their benefit biological activities. So, beside of our previous results, the results of this study can indicate that Plantaricin CS and Snakin-Z may be potent agents for treatment of infectious diseases, especially Plantaricin CS. It's suggested that the modified sequence of these peptides must be evaluated in future for improvement of advantageous and harmful properties of these peptides. 


\section{REFERENCES}

1. Izadpanah A, Gallo RL. Antimicrobial peptides. J Am Acad Dermatol 2005;52(3):38190.

2. Ganz T. The Role of Antimicrobial Peptides in Innate Immunity. Integr Comp Biol 2003 April 1, 2003;43(2):300-4.

3. Yeaman MR, Yount NY. Mechanisms of Antimicrobial Peptide Action and Resistance. Pharmacol Rev 2003 March 1, 2003;55(1):27-55.

4. Ryan L, Lamarre B, Diu T, Ravi J, Judge PJ, Temple A, et al. Anti-antimicrobial Peptides: Folding-Mediated Host Defense Antagonists. J Biol Chem 2013;288(28):20162-72.

5. Zare-Zardini H, Tolueinia B, Hashemi A, ebrahimi L, Fesahat F. Antioxidant and Cholinesterase Inhibitory Activity of a New Peptide From Ziziphus jujuba Fruits. Am J Alzheimers Dis Other Demen 2013;28(7):702-9.

6. Asoodeh A, Zardini HZ, Chamani J. Identification and characterization of two novel antimicrobial peptides, temporin-Ra and temporin-Rb, from skin secretions of the marsh frog (Rana ridibunda). J Pept Sci 2012;18(1):10-6.

7. Daneshmand F, Zare-Zardini H, Tolueinia B, Hasani Z, Ghanbari T. Crude Extract from Ziziphus Jujuba Fruits, a Weapon against Pediatric Infectious Disease. Iran J Ped hematol Oncol 2013;3(1):40-35.

8. Gonzalez-Curiel I, Castañeda-Delgado J, Lopez-Lopez N, Araujo Z, Hernandez-Pando R, Gandara-Jasso B, et al. Differential expression of antimicrobial peptides in active and latent tuberculosis and its relationship with diabetes mellitus. Hum Immunol 2011;72(8):656-62. 
9. Lorin C, Saidi H, Belaid A, Zairi A, Baleux F, Hocini H, et al. The antimicrobial peptide dermaseptin S4 inhibits HIV-1 infectivity in vitro. Virology 2005;334(2):264-75.

10. Zare-Shehneh M, Askarfarashah M, Ebrahimi L, Nasroallah MK, Zare-Zardini H, Soltaninejad $\mathrm{H}$, et al. Biological activities of a new antimicrobial peptide from Coriandrum sativum. IJB 2014;4(6):89-99.

11. Daneshmand F, Zare-Zardini H, Ebrahimi L. Investigation of the antimicrobial activities of Snakin-Z, a new cationic peptide derived from Zizyphus jujuba fruits. NAT PROD RES 2013;27(24):2292-6.

12. Seyfert UT, Biehl V, Schenk J. In vitro hemocompatibility testing of biomaterials according to the ISO 10993-4. Bioorg Chem 2002;19(2-6):91-6.

13. Rodgers K. Hemocompatibility. In: Wexler P, editor. Encyclopedia of Toxicology (Third Edition). Oxford: Academic Press; 2014. p. 834-6.

14. Schaer DJ, Buehler PW, Alayash AI, Belcher JD, Vercellotti GM. Hemolysis and free hemoglobin revisited: exploring hemoglobin and hemin scavengers as a novel class of therapeutic proteins. Blood 2013;121(8):1276-84.

15. Sharma P, Sharma JD. In vitro hemolysis of human erythrocytes-by plant extracts with antiplasmodial activity. J Ethnopharmacol 2001;74(3):239-43.

16. Oliveira VMAd, Carneiro ALB, Cauper GSdB, Pohlit AM. In vitro screening of Amazonian plants for hemolytic activity and inhibition of platelet aggregation in human blood. Acta Amazonica. 2009;39:973-80.

17. Eisenberg D. Three-Dimensional Structure of Membrane and Surface Proteins. Annu Rev Biochem 1984;53(1):595-623. 
18. Zasloff M. Antimicrobial Peptides, Innate Immunity, and the Normally Sterile Urinary Tract. Clin J Am Soc Nephrol 2007;18(11):2810-6.

19. Habets MGJL, Brockhurst MA. Therapeutic antimicrobial peptides may compromise natural immunity. Biol Lett 2012;8(3):416-8

20. Ganz T. Defensins: antimicrobial peptides of innate immunity. Nat Rev Immunol. [10.1038/nri1180]. 2003;3(9):710-20.

21. Maróti G, Kereszt A, Kondorosi É, Mergaert P. Natural roles of antimicrobial peptides in microbes, plants and animals. Res Microbiol 2011;162(4):363-74.

22. Papo N, Shai Y. Can we predict biological activity of antimicrobial peptides from their interactions with model phospholipid membranes? Peptides. 2003;24(11):1693-703.

23. Dathe M, Wieprecht T, Nikolenko H, Handel L, Maloy WL, MacDonald DL, et al. Hydrophobicity, hydrophobic moment and angle subtended by charged residues modulate antibacterial and haemolytic activity of amphipathic helical peptides. FEBS Lett 1997;403(2):208-12.

24. Huang Y-b, Wang X-f, Wang H-y, Liu Y, Chen Y. Studies on Mechanism of Action of Anticancer Peptides by Modulation of Hydrophobicity Within a Defined Structural Framework. Mol Cancer Ther 2011;10(3):416-26

25. Wieprecht T, Dathe M, Beyermann M, Krause E, Maloy WL, MacDonald DL, et al. Peptide Hydrophobicity Controls the Activity and Selectivity of Magainin 2 Amide in Interaction with Membranes. Biochemistry. 1997;36(20):6124-32. 
Table 1: The methodology of treatment of all sample groups with different concentrations of Snakin Z and Plantaricin CS

\begin{tabular}{ccc}
\hline Number of groups & $\begin{array}{l}\text { Concentration of peptide } \\
\text { Snakin Z }(\mu \mathrm{g} / \mathrm{ml})\end{array}$ & $\begin{array}{l}\text { Concentration of peptide } \\
\text { Plantaricin CS }(\mu \mathrm{g} / \mathrm{ml})\end{array}$ \\
\hline II & 5 & 5 \\
III & 15 & 15 \\
IV & 45 & 45 \\
V & 135 & 135 \\
VI & 400 & 400 \\
\hline
\end{tabular}

Table 2: The comparison of chemical properties of Snakin Z and Plantaricin CS

\begin{tabular}{cccc}
\hline Peptide name & Hydrophobic residue (\%) & Hydropathy & hydrophobic moment $(\mu)$ \\
\hline Snakin Z & 32 & -0.45 & 8.237 \\
Plantaricin CS & 26 & -0.93 & 3.645 \\
\hline
\end{tabular}



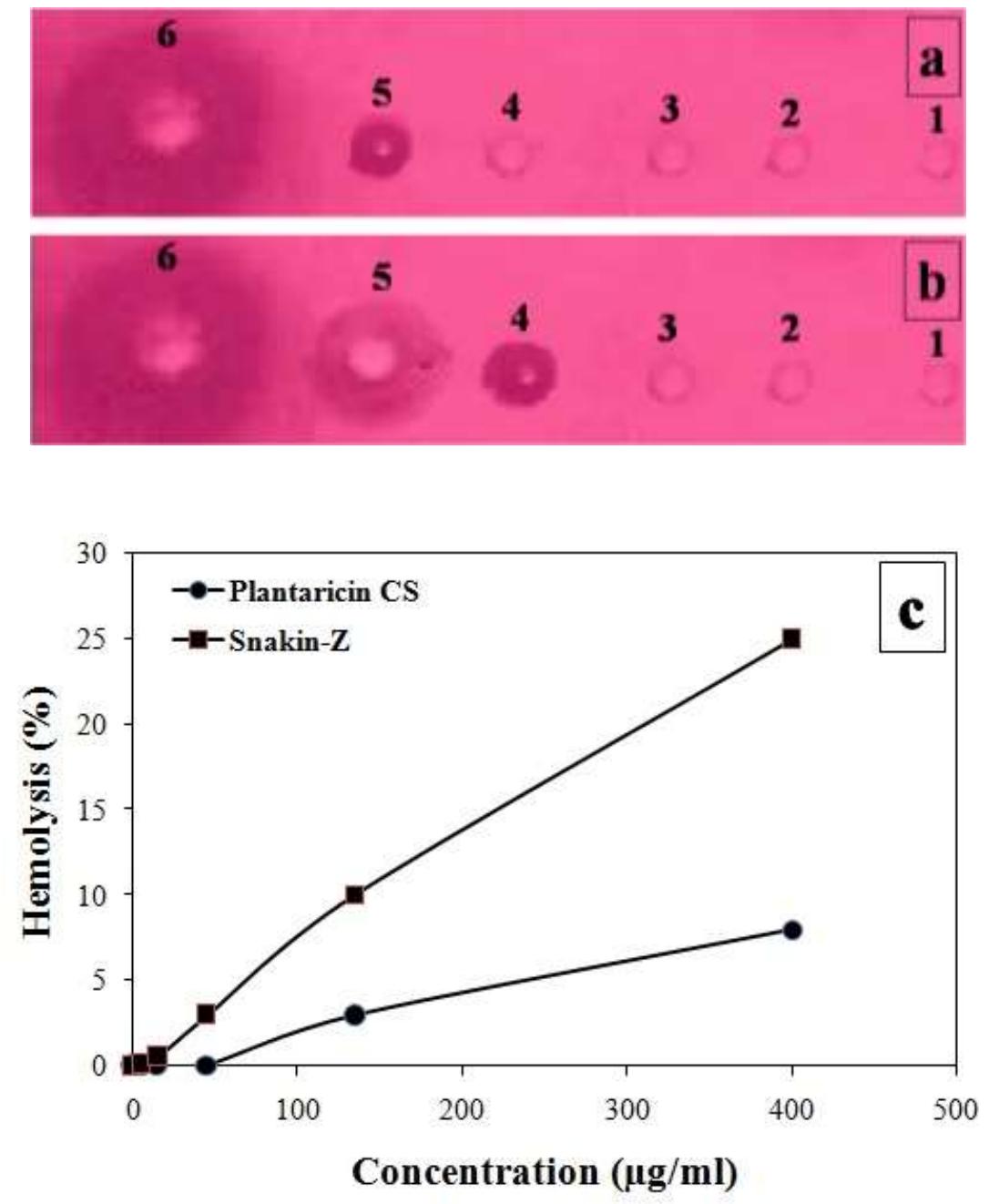

Fig. 1: Hemolytic activities of Plantaricin CS ( $a$ and c) and Snakin Z (b and c). a and b: RDA method. c: absorbance methods. 1: $5 \mu \mathrm{g} / \mathrm{ml}, 2: 15 \mu \mathrm{g} / \mathrm{ml}, 3: 45 \mu \mathrm{g} / \mathrm{ml}, 4: 135 \mu \mathrm{g} / \mathrm{ml}$ and 5: 400 $\mu \mathrm{g} / \mathrm{ml}$ of Plantaricin CS and Snakin Z. 6: Triton X-100. 
Hemocompatibility of Two Plantaricin CS and Snakin Z

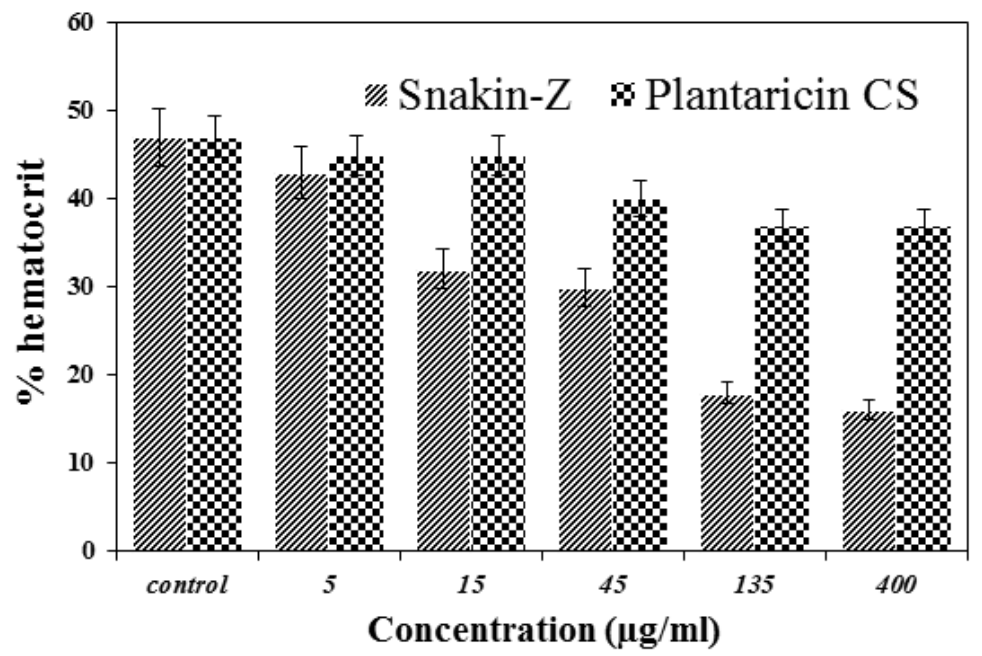

Fig. 2: Effect of different concentrations of Plantaricin CS and Snakin Z. on hematocrit.

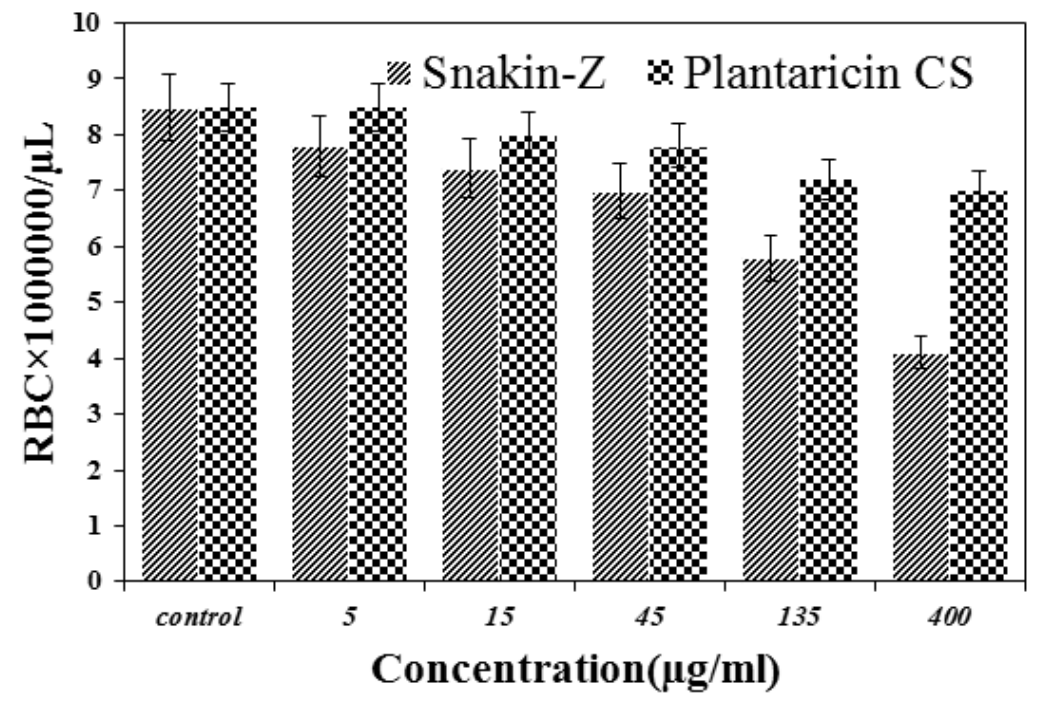

Fig. 3: Effect of different concentrations of Plantaricin CS and Snakin Z. on RBC. 


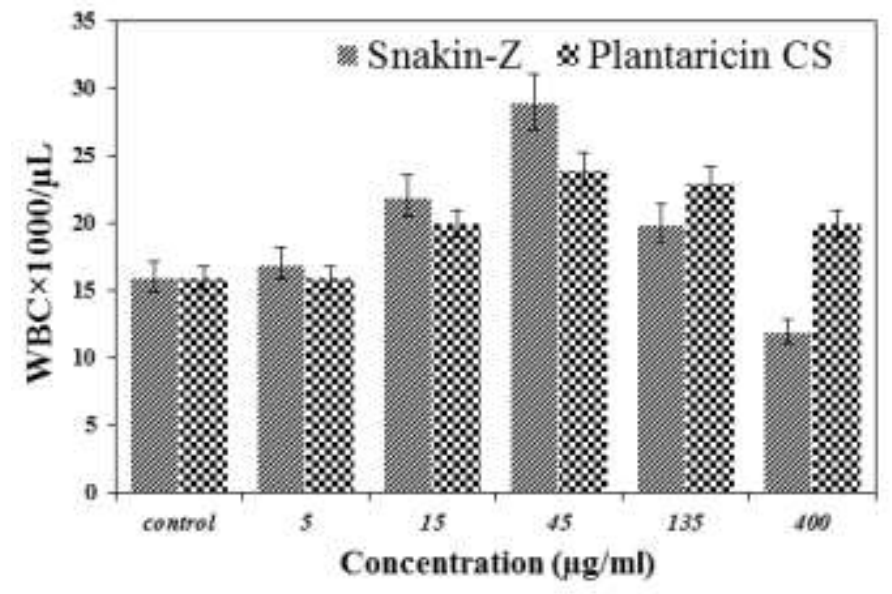

Fig. 4: Effect of different concentrations of Plantaricin CS and Snakin Z. on WBC.

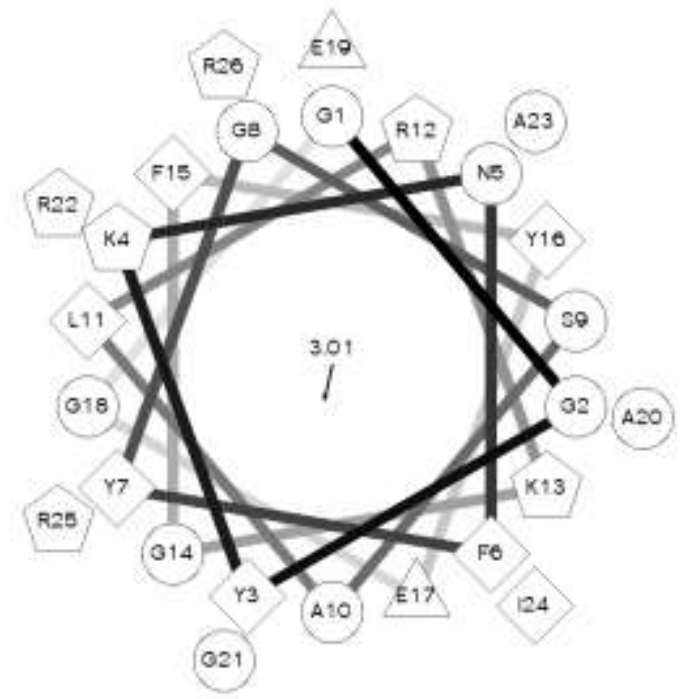

A

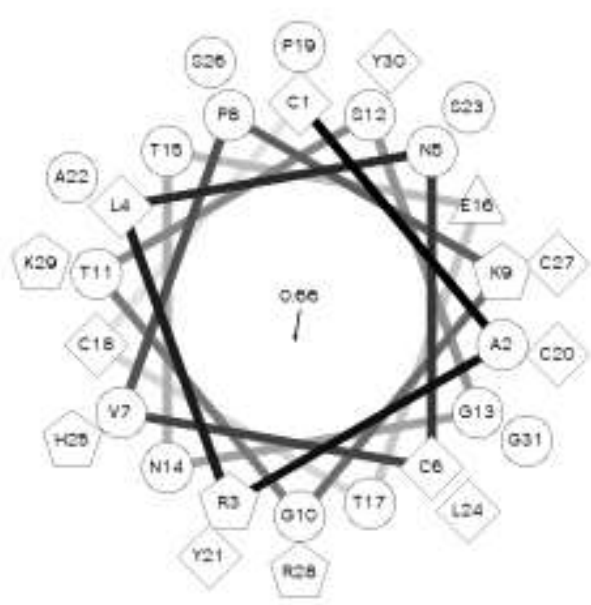

B

Fig. 5: The predicted helical wheel plots of Plantaricin CS (a) and Snakin-Z (b). By default the output presents the hydrophilic residues as circles, hydrophobic residues as diamonds, potentially negatively charged as triangles, and potentially positively charged as pentagons. 